\title{
Transmesis: Dealing with Translation in Translation
}

\author{
Roman Ivashkiv \\ University of Alberta
}

The concept of transmesis - a relatively new coinage that even among the seasoned theoreticians and practitioners of translation sometimes elicits a bewildered "trans what?" - is perhaps best illustrated in the works of Jorge Louis Borges. His character Pierre Menard from the widely anthologized story "Pierre Menard, Author of the Quixote," for example, intends (apparently disregarding Horace's famous "nec verbum verbo" reservation, if of course he happened to be familiar with it) "to produce a few pages which would coincide - word for word and line for line - with those of Miguel de Cervantes" (66). Borges's "Library of Babel" in addition to the "the minutely detailed history of the future" also contains "the translation of every book in all languages" (Ficciones 81-82). Another ingenious exemplification of transmesis can be found in Borges's "Tlön, Uqbar and Orbis Tertius." Here he depicts with great concinnity a case of untranslatability by claiming that Tlön's "Ursprache" lacks a corresponding noun for "moon" and hence only allows one to render a seemingly simple sentence "the moon rose above the river" as, verbatim in English, "upward behind the onstreaming it mooned" (33).

Coined by Thomas Beebee, the term transmesis stands for "the metaphorical conjunction of mimesis and translation" ("Attempt at a Self-Critique," par. 7, hyperlink to "transmesis") or, in other words, the representation of the translator or translation (both as a process and a product) in a work of fiction. According to Beebee, transmesis can provide a fresh insight into the process of translation. To use his own metaphor, it can allow us to penetrate "the black box of translation" ("Inside the Black Box of Literary Translation: Transmesis" 26), which, Beebee claims, "encloses the actual process of creating or recognizing equivalent messages in two or more languages" ("Milorad Pavic's Dictionary of the Khazars as Translation Fiction" 341). "The equivalence itself," he continues, "provides no clues as to the process by which it is achieved, just as a single message within any one language provides no clues as to how it achieves meaning" (ibid). From the theoretical perspective, transmesis is therefore serviceable in elucidating the complex nature of translation, particularly by shedding light on the problematic notion of equivalence and the often parodied image of translator's (in)fidelity, as well as in

\footnotetext{
${ }^{1}$ According to André Lefevere, this expression comes from Horace's Epistula ad Pisones ("Letter to the Pisones"). The full sentence in English reads "Do not worry about rendering word for word, faithful translator, but render sense for sense" (Translation, History, Culture: A Sourcebook, 15). It is important to keep in mind Doug Robinson's reservation regarding Lefevere's translation of Horace's phrase into English, though. Robinson writes,

Hence it seems perfectly natural, for example, for André Lefevere to translate Horace's 'Nec verbum verbo curabis reddere, fidus / Interpres' as 'Do not worry about rendering word for word, faithful interpreter, but translate sense for sense' (15). Horace had never heard of sense-for-sense translation, would not have been at all interested in it, or, for that matter, in translation of any sort — his remark was an attempt to warn writers against translating — but hey, if he tells us not to translate word for word, he must mean we should translate sense for sense, right?

("Translation and the Repayment of Debt," par. 7)
} 
making translators and their often underappreciated work (albeit only in fiction) more "visible." From the practical point of view, transmesis presents a considerable challenge to translators in real life, posing before them a problem of "retranslating" or translating what allegedly already is a translation. The challenge often becomes insurmountable, especially when the target language overlaps with the language of a fictional translation, confronting the translator with a twofold task: to translate something back into a language from which it is already a translation, or a trace thereof, and to retain, if at all possible, the transmetic mode of the source text (i.e. to signal to the reader that translation was part of the original even before it has been rendered into another language).

The following discussion of the practical and theoretical implications of transmesis is centered around the novel Aenem Mod (2004) (Depeche Mode ${ }^{2}$ ) by the contemporary Ukrainian writer Serhii Zhadan. Its plot may be outlined as a contemporary Ukrainian odyssey, which falls short of covering a period of ten-year travels and instead, perhaps more in line with Joyce's Ulysses, is confined to one city and province, while the story's time span is reduced to one weekend. The protagonist, who narrates the events as an adult by chronicling them in the form of a diary, offers - frequently in coarse language - a rather quotidian account of how he and his friends went looking for another friend in order to bring him to his stepfather's funeral. This purpose, which ultimately turns out to be quite inconsequential, drives the action only nominally. Meanwhile, the reality of youth life in a mismanaged post-Soviet Ukraine is exposed. Struggling to find meaning in their existence, the protagonist and his friends engage in excessive alcohol consumption, experimentation with drugs, and sporadic sex. The eponymous British rock band Depeche Mode may be interpreted to epitomize an escape from despondency. To Zhadan's characters it offers a glimpse of a different reality to which they can relate but which, purportedly due to mistranslation and almost as an illustration of the famous Derridean "différance" is simultaneously differed and deferred. In an episode that parodies a popular Ukrainian radio show, Zhadan has the host distort the facts about the band Depeche Mode and concoct a biography of Dave Gahan, its lead vocalist. The resulting inaccuracy is attributed to a mistranslation by the host's colleagues from London, which explains why the original and the translation are not "the same." Although the show is dedicated to Depeche Mode, none of the band's songs is actually played. They are always replaced by different Ukrainian popular pieces and hence deferred.

Reminiscent in terms of themes and ideas of the early Russian postmodernist writer Venedikt Yerofeev's famous Moskva-Petushki (titled in English translation Moscow Circles), Depeche Mode conveys a broadly similar message, namely, that of (re)constructing one's identity and dealing with the carnivalesque and chaotic reality. What, however, is more noteworthy about Zhadan's novel is a number of transmetic situations that are both entertaining and intellectually stimulating. In one of them, a protagonist's friend, exotically and ambivalently named Kakao (literally, "Cocoa") accidentally finds himself at a large religious gathering of more than two

\footnotetext{
${ }^{2}$ An English translation of the novel by Myroslav Shkandrij appeared recently in volume 3 of Ukrainian Literature: A Journal of Translations. Because this article was written and submitted much earlier, all translations into English of the quoted excerpts are mine.

${ }^{3}$ Derrida develops this concept in his Of Grammatology and Margins of Philosophy. A brief and accessible explanation of the term can be found in part two "Names and Terms" of The Routledge Companion to Postmodernism, edited by Stuart Sim.

${ }^{4}$ It is likely a hint at the character's drug addiction.
} 
thousand people in the eastern Ukrainian city of Kharkiv. These people come to listen to a minister from the United States, whose name, Reverend Johnson-\&-Johnson, sounds suspiciously similar - in fact, identical - to the company that manufactures skin, oral, and hair care products and is commonly associated in Ukraine with soap (and by metaphorical extension with the "brainwashing" advertising techniques). Here is how Zhadan's narrator describes the minister:

Reverend Johnson-\&-Johnson, a sun above the overcast horizon of new American preaching and pastoral ministry, a star of the largest parishes of the entire West Coast, leader of the Church of Jesus Christ (United), a pop-star, who can brainwash everyone who asks for brainwashing as well as everyone who came to see him this rainy summer morning, just on a regular weekday. Reverend Johnson-\&-Johnson doesn't give a crap about all these old-fashioned conventions. After all, he's not some old-believer to worship only on weekends: 'what kind of shit is that,' he says, 'what kind of oldbeliever shit is that?' And everybody agrees with him. ${ }^{5}$

The transmetic nature of the episode reveals itself early, even before the description of the actual process of translation begins. In a "foreshadowing" attempt, accompanied with a tinge of dramatic irony, the narrator questions the credibility of the reverend's interpreter:

[...] he [Reverend Johnson-\&-Johnson] already has his fans here; they devotedly react to the reverend's every sappy sigh, translated by some chick in an official gray suit who works for the reverend as an interpreter and who, it seems, doesn't understand him. Anyhow, she translates whatever crosses her mind, while the reverend apparently doesn't give a damn about correcting her as divine revelation hits him like a freight train, and he gets a helluva kick out of his sermon. ${ }^{6}$

The immediate and deliberate disclosure of the interpreter's alleged incompetence betrays a stereotypical bias towards translation as inherently fallible. It is suggestive of a general preconception that through translation the original message inevitably becomes fully or partially distorted. Paradoxically, however, the same passage, which introduces the interpreter as "some chick in an official gray suit," without ever mentioning her name or adding any other descriptive detail except the professional dress, informs the reader that, despite a possibly broken communication, the American pastor already enjoys popularity and appears impervious to likely mistranslations. This observation on the narrator's part only builds up the ambiguity as it tacitly implies that the reverend might have understood Ukrainian (or Russian), which is contextually unlikely, or that he could have intuitively discerned a mistranslation, which is also implausible in view of the audience's positive reaction. What makes the whole situation even more convoluted

\footnotetext{
5“Преподобний Джонсон-і-Джонсон, сонце на затуманеному небосхилі нового американського проповідництва, зірка найбільш масових приходів на всьому Західному побережжі, лідер Церкви Ісуса (об'єднаної), поп-стар, який вправляє мізки всім, хто цього прагне і хто прийшов до нього цього літнього дощового ранку, просто посеред тижня, преподобний Джонсон-і-Джонсон плювати хоче на всі ці умовності, він не старовір який-небудь, аби відправляти свої служби лише по вихідних, що за гівно, говорить він, що за старообрядне гівно, і всі з ним погоджуються” (Zhadan, Depeche Mode 27-28). 6 “...у нього тут уже свої фанати, вони віддано реагують на кожне сопливе схлипування преподобного, перекладене для них якоюсь тьоткою в сірому офіційному костюмі, яка працює в преподобного перекладачкою, і яка його, здається, не розуміє, у всякому разі перекладає вона що попало, а самому преподобному, очевидно, просто в падло її корегувати, очевидно, откровення боже накриває його з головою, його просто пре під час проповіді, ...” (28-29).
} 
is Zhadan's peculiar use of synecdoche. It is not words, phrases, or sentences that the reverend's interpreter translates but rather his "every sappy sigh," which shifts the emphasis from verbal to nonverbal communication.

As the episode continues, the minister, wearing a gold Rolex watch, becomes very excited before his appearance:

The Reverend is getting all pumped up in the dressing room, swallowing some pills, drinking lots of decaf, loudly reciting passages from the Khowlee Byebill, and demanding that the interpreter repeat after him. Downcast, she remains silent, which seems to work him up even more. The Reverend begins to experience the first bouts of divine revelation, which in his case resemble a diarrhea attack it enwraps and absorbs him and he can't do shit about it. Some guy from the organizing committee walks in and says it's time... time to go, people are waiting. The Reverend takes a sizeable sip of his unhip decaf from a large plastic mug. A stain spreads swiftly on his snow-white shirt. Shit, he says, fuckin' shit. The interpreter jumps in, trying to translate the interjection: "Sheet," she says to the organizing committee guy, but he waves her away. ${ }^{7}$

Here Zhadan playfully elaborates on the transmetic details, preceding the act of interpretation. In addition to incorporating an English word combination "the Holy Bible," potentially recognizable in other languages, into Ukrainian ${ }^{8}$ and adjusting it grammatically (i.e. declining it as if it were a genuine Ukrainian lexeme), the narrator comments on the interpreter's attitude and behavior. At the end of the passage, when the interpreter tries to translate the reverend's uncouth interjection to an official, he stops her, either demonstrating a lack of interest or suggesting that translation in this instance is indeed redundant. In any case, it may be construed as a hint at the uselessness of the interpreter's service.

When the reverend finally addresses the crowd and as the sermon progresses, the narrator's speculation regarding the interpreter's incompetence proves to be a fact. It quickly becomes obvious (to the reader, but not to the fictional audience in the novel) that the only thing the interpreter translates "correctly" is just the reverend's greeting "Dear brothers and sisters" (31). The rest of Johnson- $\&$-Johnson's sermon gets progressively distorted (embellished?) to the extent that the "chick in an official gray suit" ends up making up her own story and adding details that are not even remotely relevant. Of course, the original sentences followed by inaccurate renditions create a comical effect as Zhadan generously spices up these mistranslations with hilarious puns and provocative double entendres. Paradoxically, Reverend Johnson-\&-Johnson's sermon turns out to be quite successful in translation, notwithstanding a misunderstanding that takes place when the preacher tries to interact with the audience and is momentarily baffled by an unexpected response, caused by the interpreter's digression. For a second, Johnson-\&-Johnson even doubts if his words are being rendered accurately, but in the

\footnotetext{
7 “ Преподобний накручує себе в гримерці, ковтає якісь пігулки, п'є багато кави без кофеїну, і голосно рецитує щось із голі байбла, примушуючи перекладачку повторювати, перекладачка понуро мовчить, преподобного це заводить ще більше, в нього вже перші приступи божого откровення, в нього це як срачка, його просто розриває і все тут. Заходить хтось із адміністрації, час, говорить, час іти, народ вже чекає, преподобний сьорбає з великої пластикової кружки свою безпантову каву, обливає нею свою білосніжку сорочу, шіт, говорить, факін шіт, перекладачка пробує перекласти це чуваку з адміністрації, але той лише відмахується" (29).

${ }^{8}$ The phrase "from the Hole Bible" is transliterated in Ukrainian as “із голі байбла" (29). Moreover, it is used in the genitive case, required by the Ukrainian preposition is 'from.'
} 
end, he is confident that his sermon has produced the desired effect on the crowd. In a brief discussion with one of the administrators, who "stares at him lovingly" (35), the reverend says, "Oh, I had them, didn't I? I totally pulled it off" and then reassures himself again, "yeah, holy shit, I had them real good" (35). Despite an explicit discrepancy between the original and the translation, which, it should be emphasized again, is only evident to the reader but not to the reverend himself or to his audience, the latter's response is quite positive. Nobody, except the omniscient narrator, seems to doubt either the credibility of the preacher's words or the reliability of his interpreter. In fact, some attendees are so deeply moved by the sermon that they burst into tears. The transmetic situation is particularly comical due to the conflation of the sermon's solemn style with the irreverent register of its interpretation. In translation, the inspirational story about a girl whose life was changed when she opened her heart to Jesus turns into a preposterous account of what could be read as a fallen woman's life full of obscene details. Most of them are concocted by the interpreter as she hardly concerns herself with being "faithful" to the original message, thereby allowing Zhadan to poke fun at the translator's infidelity in light of the famous Italian saying, "traduttori, tradittor" (translators, traitors)."

The notion of "(in) fidelity" belongs, of course, to the realm of theory, which in translation studies is often irreparably divorced from practice, and will be addressed later. Meanwhile, of a more immediate practical concern is the approach that the real translator may take to rendering this episode, featuring a translation from English into Ukrainian, back into English. Part of the solution to this challenge lies in taking a closer look at the technique that Zhadan employs to construct the transmetic situation. While the minister's talk - originally in English - is presented in the book in Ukrainian, the translation, which is accompanied by the narrator's commentaries and reported speech, is offered in parentheses and also in Ukrainian. ${ }^{10}$ Zhadan, therefore, imitates a translation process by paraphrasing the source text in the same language, which is reminiscent of what Roman Jakobson described in his famous tripartite distinction ${ }^{11}$ as intralingual translation or rewording (114). Paronomasia, which according to the Oxford English Dictionary stands for "wordplay based on words which sound alike," is a device that Zhadan employs effectively throughout the entire episode. Premised on ambiguity, paronomasia serves to undermine the stability and finality of meaning. For example, Reverend Johnson-\&-Johnson says, “Господь маніпуляціями своїх божественних рук зібрав нас тут до купи!” (31), which in English reads "Through the manipulation of his divine hands, the Lord has gathered us together." Evidently, the interpreter renders this message very "freely" when she says: "(Господь проробив певні маніпуляції, - перекладає вона. - Купу)” (31). The verbatim translation into English is "(The Lord has completed certain manipulations, she translates, [which resulted in] a pile." In addition to one of its denotative meanings, "a great amount of something," the Ukrainian word kyna, "pile" in this context conjures up the collocation "a pile of manure" (or "a pile of shit"), thereby creating a witty ambivalence. This mistranslation is not only amusing

\footnotetext{
${ }^{9}$ In his essay "Lesen ist wie Ubersetzen," Hans Georg Gadamer attributes this saying to Benedetto von Croce (Ästhetik und Poetik I, Volume 1, 279).

${ }^{10}$ Considering the geopolitical and linguistic situation in eastern Ukrainian Kharkiv, where most of the population today speaks Russian rather than Ukrainian, it is much more likely that the translation would be into Russian. This may raise a separate issue about the transmetic nature of the entire novel, which, however, goes beyond the scope of this study and merits a separate sociolinguistic investigation.

${ }^{11}$ In his essay "On Linguistic Aspects of Translation," Jakobson distinguishes between the three kinds of translation: interlingual, intralingual, and intersemiotic (114).
} 
because of the pun Zhadan makes on the basis of the Ukrainian words dokynu, "together" and kyna, "pile," which share the same stem, but also because it subtly implies that the reverend may treat his audience accordingly. ${ }^{12}$ If, on the one hand, the real translator were to stay "faithful" to the original by trying to recapture (or "compensate for") the word kyna in English, much of the jocosity in this passage would have to be sacrificed. Although the figurative meanings of "large amount" do overlap in both languages, connotations of the word "pile" in English and in Ukrainian are considerably different. Whereas in English the noun "pile" carries multiple meanings and can additionally serve both as a transitive and intransitive verb, in Ukrainian it is strictly a noun, of which an adverbial form doкynu, "together," can be derived. This is a grammatical property that Zhadan aptly exploits. The English idiom "to make a pile," in the sense of "to make a fortune," naturally does not bring forth similar associations in Ukrainian and, as the above example suggests, stands for something quite opposite. On the other hand, the translator who adopts a more playful approach to this sentence instead of seeking correspondents between the two languages may enjoy a whole plethora of creative possibilities. One of them is to explore the phonetic similarity between the final syllables of the words "manipulation" and "copulation," which not only creates a realistic impression that the interpreter might have indeed confused the two words but at the same time conveys the ironic, even irreverent undertones in the speech of both the interpreter and the narrator. A possible translation would then be the following: "In an act of divine manipulation, the Lord has gathered us together here. (We have been gathered here today by the Lord in an act of divine copulation, she translates.)" Another approach that merits further exploration is to experiment with the words "manipulation" and "masturbation," which are also close in sounding (i.e. the "ma" alliteration and the same-suffix endings) and produce a comic effect of confusion.

In a similar example, the reverend appeals to God and proclaims, "Господи, кажу я! ... Подивись на цих мюдей, котрі тут зібрались цього ранку!” which literally translates as “Oh Lord, I say! Look at these people who have gathered here this morning." According to the interpreter's version, the sentence not only gets somewhat truncated but also sounds rather dubious: “(Він каже - 'Господи’. ... Зранку вже зібрались).” If the interpreter's sentence were translated into English verbatim, it would read "(He says, 'Oh Lord' ... 'They already got together in the morning')." The subtle flash of humor mixed with reproach in Ukrainian would not be grasped by the English reader, even though technically such a translation would be accurate. Throughout his sermon the reverend tries to maintain a devout and inspirational tone. The interpreter's tone, conversely, becomes gradually more condescending and vulgar. The resulting disparity in tones contributes to jocularity as here Zhadan might be poking fun at two unfortunate tendencies in consecutive interpreting. The first one is the proclivity of novice interpreters to use indirect speech where the first person is used in the original, which happens as a result of trying to "separate" the message from the messenger. The second one is a common propensity among interpreters for omitting information that they either fail to comprehend or believe to be inconsequential. Whereas these metalinguistic details might have been incorporated by Zhadan unwittingly, the sentence evokes laughter primarily because it brings up the infeasibility of gathering such a large audience on a weekday morning when people are supposed

\footnotetext{
12 "Accordingly" in this context suggests that the pastor may treat his audience badly (i.e. "like shit") or that he doesn't care ("doesn't give a shit"), which, judging from his frequent use of the word "shit," is even more likely.
} 
to be at work. Although the sentence is open to interpretation, possible readings could be that all the attendees have come for freebies or to see a show or maybe even (which might be an exaggeration) in expectation of having fun and getting drunk. Interestingly, from the linguistic perspective the discrepancy between the reverend's original sentence and its translation does not stem from semantic differences (i.e. polysemy) but is highlighted rather through the peculiarities of syntax. Whereas the original subordinate clause "котрі тут зібрались цього ранку" (“[реорle] who have gathered here this morning") has direct word order, the interpretation "Зранку вже зібрались" ("In the morning already [they] gathered") is not only an inversion but also an elliptical construction with the contextually implied subject. The translation of this seemingly short and simple sentence into English is problematic for a number of reasons. While seeking equivalences at either semantic or syntactic levels is a priori futile, interpreting the sentence explicitly in a certain way is also a debatable strategy. Even if this allows the translator to capture some of the humor, it eliminates the ambiguity of the original in favor of a specific reading. In other words, provided the translator takes poetic license in modifying both the reverend's and the interpreter's sentences, solely making the mistranslation funny will not be sufficient as ideally it also needs to be ambiguous in order to allow the English reader to keep the interpretative options open. While a possible translation of the reverend's sentence could be "Look at these thirsty people, oh Lord. They are here to get a drink of your living water," the interpreter's mistranslation may then be rendered in the following way: "Look at these rusty people, oh Lord. They are here to get a drink and they ain't leaving without it." A downside of such an approach, however, is that despite an attempt to create a totally new situation by alluding to the concept of "living water" from a passage in the Gospel of John, titled "Jesus Talks with a Samaritan Woman" (New International Version, John 4.10-11) and by playing with the phonetic similarities between the words "rusty" and "thirsty" as well as with a feasible (and appropriately Slavic) confusion of the pronunciation of the English words "living" and "leaving," this translation explicitly favors an interpretation in which the crux of the joke rests on drinking. In the original, though, the emphasis on drinking is less straightforward.

When the reverend decides to demonstrate to his audience the love of Jesus by telling an inspirational real-life story, he says: "Я хочу розповісти вам одну історію, я хочу вам показати на конкретному прикцаці, щоб ви зрозуміли, що я маю на увазі” (31). Verbatim it can be translated as "I'd like to tell you a story and draw a specific example so that you can understand what I mean." While in itself this opening sentence does not say much (except that a story will follow) and simply serves as a transition to the main point, in the interpreter's condensed and confused rendition it acquires a new, rather unexpected tinge of meaning. She says, " $Я$ хочу вам, наприклаА, показати, ви розумієте що я маю на увазі" (31), which literally reads "I'd like to show you, for example. You understand what I mean." What would generally be considered an "accurate" translation, that is the translation that semantically and syntactically approximates the original, hardly conveys the witty ambiguity of how the reverend's interpreter chooses to "reword" his message. Although as in the two examples above, any definitive interpretation is problematic, implications of the interpreter's emphasis on the verb nоказати, "to show" range from a hint of exhibitionism to an elliptical gesture towards a whole plethora of idiomatic expressions in Slavic languages. Examples in Ukrainian include показати, де раки зимують and 
показати, на чому горіхи ростуть. ${ }^{13}$ Based on nonsensical images that are generally untranslatable, both idioms carry the sense of "showing somebody who the boss is." Perhaps, one of the most notable idioms with the verb "to show" in Russian is attributed to the Soviet leader Nikita Khrushchev, who during the 1960 UN General Assembly in New York pounded his shoe on the table and threatened the US and other western governments to показать кузькину мать. ${ }^{14} \mathrm{It}$ roughly translates into English as "to give somebody a hard time" (Ivanov 12). ${ }^{15}$ What the reverend intended to "show" by giving an example or rubbing it in to his devotees who the boss is remains unclear. Once again, this raises the problem of recreating ambiguity and preserving the transmetic mode of a possible confusion on the interpreter's part. One solution, however imperfect, may be found in the English homonym "mean," which as a verb stands for "denoting" or "signifying" and as an adjective for the quality of being "nasty" or "obnoxious." Moreover, on the denotative level the verb "mean" is also contextually fitting because it is precisely the word the reverend uses in the sentence. Based on this ambiguity, a translation into English may then be the following: "I'd like to tell you a story and draw a specific example so that you can understand better what I mean. (I'd like to tell you a story and draw a specific example. And you'd better understand that I'm not mean.)"

The transmetic episode in the novel continues hilariously in this vein as Zhadan often resorts to racy vocabulary and presents the mistranslation, or rather a parody of translation, in a way that seems exaggerated to the point of being almost absurd. At first glance, the specific targets of his transmetic parody are all the participants of this communicative act. They are the American pastor, who showcases cultural insensitivity and religious incommensurability; the "unfaithful" interpreter, who gets across a totally different message; and the gullible audience, so desperate about its sociocultural predicament that it is ready to believe in anything even if it is utter nonsense. But on a deeper level, transmesis in Depeche Mode invites the careful reader and the translator (as indeed the "closest" of all readers) to question the very principles of equivalence and fidelity, which for a long time have underlain our understanding of translation. Even today they continue to define the goal of translation as a product as well as the nature of translation as a process. The idea of equivalence as a major premise in translation studies was first debunked back in 1988 when Mary Snell-Hornby unequivocally argued that equivalence is illusory. It "is unsuitable," she wrote, "as a basic concept in translation theory: the term equivalence, apart from being imprecise and ill-defined [. . . ] presents an illusion of symmetry between languages which hardly exists beyond the level of vague approximations and which distorts the basic problems of translation" (Translation Studies: An Integrated Approach 22). Nonetheless, equivalence has maintained wide currency in both academic and popular translation discourse as even today the term's usage persists in teaching and learning resources, publication and submission requirements, critical reviews, and assessments of translated works. Its definition, however, has always remained vague and controversial. According to a recent and authoritative companion,

\footnotetext{
${ }^{13}$ Verbatim, "to show [a place] where crabs spend winters" and " to show [a tree] on which nuts grow," respectively.

${ }^{14}$ Verbatim, "to show Kuzka's mother," Kuzka being a diminutive form of a male proper name Kuzma.

${ }^{15}$ This translation is a euphemism for a more emotional Russian expression. Interestingly, according to William J. Tompson, "Khruschev himself began to beat the tabletop with his shoe. The Assembly's presiding officer broke his gavel attempting to restore order, but the unflappable Macmillan simply requested a translation 8 " (230). One may only wonder what the English interpreter came up with in this situation and, even more importantly, what the English-speaking audience inferred from whatever the interpretation was.
} 
The Routledge Companion to Translation Studies (2009) edited by Jeremy Munday, equivalence "defines the translational relationship between either an entire ST and a TT or between an ST unit and a TT unit in terms of the degree of correspondence between the texts and the text units" (185). ${ }^{16}$ While stating what equivalence does, this explanation hardly clarifies what it actually is. Moreover, it relies on a similar concept (i.e. correspondence), which in its turn requires a separate definition. Going back to the ancient "word-for-word" vs "sense-for-sense" debate, which was ingeniously problematized by Borges in "Pierre Menard, Author of Don Quixote," equivalence found its most insightful theoretical elaboration in the work of Eugene Albert Nida, whose approach generally came to be known as "dynamic equivalence," and also in the work of the so-called skopos theorists, who focused primarily on the purposes and functions of translation. As the forthcoming discussion will demonstrate, however, the application of either one in the context of transmesis in Zhadan's Depeche Mode raises questions regarding their validity and calls for an alternative approach to translation that does not rest on equivalence and is not governed by binary oppositions.

Nida, who initially dealt specifically with Bible translation, authored the groundbreaking Towards a Science of Translating. In it, he asserted that "[s]ince no two languages are identical, either in the meanings given to corresponding symbols or in the ways in which such symbols are arranged in phrases and sentences, it stands to reason that there can be no absolute correspondence between languages" (156). Consequently, Nida proposed to distinguish between formal and dynamic equivalence. The latter, he maintained, is premised "on the principle of equivalent effect" whereby "the relationship between receptor and message should be substantially the same as that which existed between the original receptors and the message" (159). This theory, however, has several considerable limitations. It is virtually impossible to compare the effects; measure the similarity of responses (i.e. relationship between the receptor and the message) either in the original or translated contexts; or identify the specific audiences, which may be quite heterogeneous and whose reactions may significantly vary. In Zhadan's novel, assuming Nida's claim about the "equivalent effect" is correct, had Reverend Johnson-\&Johnson's sermon been translated "properly," it would have had the same enlightening impact on the Ukrainian audience as it supposedly had on his numerous congregations in the United States. According to his own remarks, the reverend is quite satisfied with his performance. But the desired effect, whatever it might have been, has been achieved in spite of or perhaps even due to a distorted translation. In other words, any degree of equivalence between the original and translated texts does not necessarily ensure the achievement of the same or similar effect on the target audience.

The skopos theorists, namely the German scholars Hans Vermeer and Katharina Reiss, have advanced our understanding of equivalence by distancing their theorizing from the previous linguistic-oriented approaches. But although its overall emphasis has been shifted to the functions (rather than the effects) of the original text and its translation, the skopos methodology continues to rely to some extent on the idea of equivalence. Specifically, Reiss defines translation as "a bilingual mediated process of communication, which ordinarily aims at the production of a TL [target language] text that is functionally equivalent to a SL text" (160). In an attempt to broaden the skopos theory, Vermeer, who has been primarily concerned with the purpose of

${ }^{16} \mathrm{ST}$ and TT standing for source and target texts, respectively. 
translation, advocates paying closer attention to the target text. As Christina Schäffner summarizes,

[t] he main point of this functional approach is the following: it is not the source text as such, or its effects on the source-text recipient, or the function assigned to it by the author, that determines the translation process, as is postulated by equivalence-based translation theories, but the prospective function or skopos of the target text as determined by the initiator's, i.e. client's, needs. Consequently, the skopos is largely constrained by the target text user (reader/listener) and his/her situation and cultural background. (236)

Notwithstanding the functional approach's close attention to the target text and the recipient audience, both Vermeer ${ }^{17}$ and Reiss still propound "the fidelity rule" of intertextual coherence, which, according to Shuttleworth and Cowie, depends on the "consistency between a) the original ST message intended by the text producer, b) the way the translator interprets this message, and c) the way in which the translator encodes the message for the TT recipient" (qtd. in Van Vaerenbergh 50). While skopos theory may be useful in non-literary, scientific or technical texts (such as, among many others, contracts, manuals, or certificates), in which the text purpose(s) and function(s) can be identified more precisely and then followed as a governing principle, in literary translation these functions will always be multiple, equally important, subject to interpretation, and contingent both on the context and the reader's perspective. The author's intention - a term that Reiss employs to explain how the text acquires a function, which then needs to be determined and reproduced by the translator ${ }^{18}$ - has been discarded as a valid operational concept since Roland Barthes, in his "obituary" of the author, famously asked "Who is speaking thus?" (Image, Music, Text 142). One could, of course, argue that in Depeche Mode the rhetorical purpose of Reverend Johnson-\&-Johnson's sermon is persuasive, while his aim is to convert the despondent population in post-Soviet eastern Ukraine from communist-imposed atheism (or, perhaps, “dormant" Orthodoxy) to western Protestantism. But the reverend's interpreter never seems to concern herself with this objective. Nor is she particularly cognizant or considerate of her target audience ${ }^{19}$ and, even more importantly, of the organizers' needs and intentions. In their turn, both Johnson-\&-Johnson and the organizing committee representative, who as commissioners of the translation, according to Reiss and Vermeer, should play a significant role in articulating their goals, surprisingly demonstrate flagrant disregard of the translation. But because the sermon is well received by the public, the reverend's objective is successfully achieved despite all of these inconsistencies.

One of the main reasons why Nida's dynamic equivalence or the functional skopos approach cannot effectively underpin the philosophy of translation is that both theories are grounded in the idea of ultimate sameness, be it the achievement of the same effect or the reproduction of

\footnotetext{
${ }^{17}$ According to Snell-Hornby, in his later work Vermeer leaned more towards a post-structuralist tendency to question the primacy of the original text and author (The Turns of Translation Studies 62).

${ }^{18}$ Reiss argues that " $[\mathrm{t}]$ hrough the intention, verbalized by the author in his text, this text receives a communicative function for the process of communication. In order to be able to establish this intention the translator receives significant assistance if he determines to which text-type and text-variety (relevant for translating) any given text belongs" (qtd. in Venuti 161).

${ }^{19}$ Part of her attitude is disclosed at the end of the sermon when she makes an obnoxious comment about the attendees with disabilities.
} 
the same function. But even if one reads Zhadan's text solely as a parody ${ }^{20}$ of translation, one of the main objects of ridicule in his transmetic episode is precisely the idea of sameness, which is shown to be impossible on either a linguistic or cultural level. Moreover, the impossibility of sameness is highlighted by the very technique of paraphrasing Zhadan uses in this transmetic episode, implying that even in the same language it is not feasible to reproduce the exact same meaning. Instead, the reverend's anonymous interpreter creates a new, different text, which implicitly signals that it is more likely in difference, plurivocity, and multiplicity, rather than in sameness or equivalence, that translation finds a life of its own. Unable (for whatever reason: misunderstanding, linguistic incompetence, cultural incongruity, personal indifference etc.) to find what the reader or the narrator may think are the exact correspondents of the reverend's words, the interpreter relies on the traces of meaning that she is able to catch in the original message. And although she almost always gets sidetracked by following different traces or sensemaking paths, to the fictional audience in the story as well as to the reader her version turns out to be no less gripping (even if not quite rigorous) than the original of which it is a translation. Especially in cases of untranslatability, therefore, the process of translation essentially comes down to playing with traces of meaning in both texts, a liberating act that is premised on the notion of supplementarity and hence entails deviations, substitutions, additions, and omissions.

Simultaneously, this process is also inherently predicated on freedom and the Barthesian jouissance ${ }^{21}$ of the text.

Unlike equivalence, which presupposes the existence of a fixed and definite origin that needs to be preserved or compensated for, a trace marks the absence of what was present in the original and uncovers multiple chains of supplements that both substitute the sign and add to it, making the final resolution of meaning impossible. In the context of translation studies, a trace might be metaphorically compared to an echo, which Walter Benjamin mentions - in addition to the release of "pure language" - in defining one of the translator's tasks: to find "that intended effect [Intention] upon the language into which he is translating which produces in it the echo of the original" ("The Task of the Translator" 76). ${ }^{22}$ Although both "trace" and "supplement," two fundamental concepts in Derrida's thought, evade precise definitions, in the introduction to her translation of his seminal Of Grammatology, Gayatri Chakravorty Spivak explains that by "trace" Derrida referred "to the part played by the radically other within the structure of difference that is the sign" (xvii). Derrida, who throughout his writing also uses similar terms such as "archetrace," "non-trace," and "originary trace" states that "[t]he trace is in fact the absolute origin of sense in general. Which amounts to saying once again that there is no absolute origin of sense in general" (Of Grammatology 65). In The Tain of the Mirror: Derrida and the Philosophy of Reflection,

\footnotetext{
${ }^{20}$ Elaborating her definition of parody as "imitation with critical ironic distance," Linda Hutcheon claims that "parody is repetition, but repetition that includes difference" (A Theory of Parody 37).

${ }^{21}$ In his The Pleasure of the Text, Barthes distinguishes between texts of pleasure and bliss (one of the possible translations of jouissance). He writes, "Text of pleasure: the text that contents, fills, grants euphoria; the text that comes from culture and does not break with it, is linked to a comfortable practice of reading. Text of bliss: the text that imposes a state of loss, the text that discomforts ..., unsettles the reader's historical, cultural, psychological assumptions, the consistency of his tastes, values, memories, brings to a crisis his relation with language" (14).

${ }^{22}$ Unlike Nida, Benjamin, who also uses the word effect, writes about the effect on language rather than on the audience, which despite being more figurative and less pragmatic, is at the same time less categorical, thereby granting the translator more poetic license.
} 
Rodolphe Gasché explicates this apparent paradox thusly: the trace for Derrida "designates something of which the metaphysical concepts of trace and presence are the erasure. From Derrida's analysis of Heidegger's concept of "die frühe Spur," it follows that the trace is the necessarily metaphysical concept that names an originary tracing and effacement..." (186). According to Gasché, "it [the trace] names something of which presence and trace, or more generally self and Other, are the erasure within the discourse of philosophy... Indeed, despite the self's traditional subjection of the Other to itself, its own identity is a function of its demarcation from the Other, which thus becomes endowed with essential autonomy" (187). The arche-trace, he continues, is then "the constituting possibility of this differential interplay between self and Other" (187). Gasche's explication may inform the theory of translation through the following analogy: if the original and translated texts respectively could be metaphorically compared to the self and the Other, the autonomy of the latter would be justified and guaranteed by what Gasche calls the "differential interplay." In that case, the relationship between the original and the translation will be defined not by the delusive ideal of sameness, which forces the translator to struggle constantly in order to achieve equivalence and be ultimately doomed to failure, but rather by the differential interplay whereby the translator playfully engages with the traces of meaning to create new meanings and, very much like the original author, to expand the potentialities of language. After all, to paraphrase T.S. Eliot, the translator's "direct duty," very much like the poet's, is also primarily to language and not only to the original work or its author. ${ }^{23}$

Based on my own attempts to render Zhadan's transmetic puns and double entendres, however, a viable counterargument in defense of equivalence could be that while it may indeed be unattainable at the phonological, morphological, semantic or syntactic levels, at least at the pragmatic (or communicative) level translators who want to complete their task and not just philosophize about it are nevertheless bound to seek some sort of compensation to preserve a pun or recreate a comical effect. Ostensibly commonsense, such thinking, however, is misleading because it derives from the negative rhetoric of inferiority, which unfortunately shapes most discussions of translation, including, ironically, to some extent my own. It is the rhetoric of irreparable loss, inevitable sacrifice, and always only partial compensation; rarely of cross-cultural gain, playful experimentation, and interlingual discovery. This rhetoric, it must be pointed out, has been shaped largely due to the conventional dichotomies, without which it is almost impossible to discuss translation: author/translator, source text/target text, source language/target language, translation as a process/translation as a product, word-forword/sense-for-sense, formal equivalence/dynamic equivalence, to domesticate/to foreignize, literal/figurative, craft/art, etc. As poststructuralist thinkers have suggested, one of the constituents in such hierarchical binary oppositions is often prioritized whereas the other one is believed to be inferior. In regard to translation, this is particularly true of such oppositions as original/translation and author/translator. The negative influence of these dichotomies lies not only in undermining the relationship of equality but, even more alarmingly, in stifling rhizomatic (as opposed to dualistic) thinking about translation. While translation theories based on binaries direct the translator to strive for an allegedly "more adequate" component of the pair, they

\footnotetext{
${ }^{23}$ In an essay "The Social Function of Poetry," T.S. Eliot claims that the poet's "direct duty is to his language..." (qtd. in Murphy 26).
} 
privilege one binary constituent over the other. Transmesis, on the other hand, helps to transcend these dichotomies and encourages us to review the apologetic translation discourse, which is primarily tailored to defend (or criticize) translations rather than celebrate them. This, of course, is not to say that all translations should be considered acceptable or that they should only be praised. But instead of focusing more on creativity, novelty, and the enrichment of language, many discussions of translation continue to be driven by a tendency to denounce (or downplay) instances of "infidelity" and to deplore decisions to depart from the original as "unfaithful."

In fact, such fidelity-oriented thinking about translation has become so deeply entrenched among scholars and critics that even Philip E. Lewis, who in his brilliant performative (and, perhaps, as well transmetic) piece, "The Measure of Translation Effects" 24 seems to advocate "the strong, forceful translation that values experimentation, tampers with usage, seeks to match the polyvalencies or plurivocities or expressive stresses of the original by producing its own" (270), is himself susceptible to relying on the fidelity criterion. Calling fidelity one of the "basic scruples of conventional translation" (270), he writes that " ... the demand is for fidelity to much more than semantic substance, fidelity also to the modalities of expression and to rhetorical strategies" (270) and that "the problem is rather how to compensate for losses and to justify (in a graphological sense) the differences - how to renew the energy and signifying behaviour that a translation is likely to diffuse" (271). Consequently, Lewis's ingenious approach, (inspired transmetically ${ }^{25}$ by Derrida, who in "The Retreat of Metaphor" writes that "une 'bonne' traduction doit toujours abuser' - 'a 'good' translation must always commit abuses.' Or perhaps 'a good translation must always play tricks"' (269), comes to be generally known under the term "abusive fidelity." 26 As in George Steiner's famous four-step "hermeneutic motion," consisting of trust, aggression, incorporation, and restitution (After Babel: Aspects of Language and Translation), at face value the terms "abusive fidelity" and "aggression" are imbued with some sort of vehemence. Especially in Lewis's case, however, more emphasis should probably be placed on what he himself calls "the playful tinkering" because essentially his approach is more about the freedom to "seek after the unthought or unthinkable in the unsaid or unsayable" (270) rather than about seeking fidelity.

By representing translation with all its complexities, delights, and pitfalls and by portraying the figure of the translator in different capacities, ranging from the transmitter of information and cultural mediator; to traitor, counterfeiter, and subservient scribe; to artist, author, and creator, transmesis as a literary theme not only helps to make translators more visible and empowered, but also invites us to reconsider our attitudes to translation in general. On the other hand, the analysis of transmesis as a literary device that often poses insurmountable challenges to translators, suggests that if the process of translation is governed by equivalence and fidelity, the discussion of translation as a product will be inevitably centered on loss, compensation, and sacrifice. If, conversely, translation is conceived of as an essentially playful act that allows the

\footnotetext{
${ }^{24}$ It is performative and to some extent transmetic because, while theorizing translation from a philosophical perspective, Lewis simultaneously performs the translation of his article by rendering it from the original French version, titled "Vers la traduction abusive," into English. Among other things, his approach is exemplified by a drastic difference in the two titles.

${ }^{25}$ I believe this to be transmetic because although Lewis offers a more idiomatic translation "to play tricks," he nevertheless uses a more awkward-sounding phrase "to commit abuses" in English which is "closer" to Derrida's original French.

${ }^{26}$ It can be found in Giuseppe Palumbo's Key Terms in Translation Studies.
} 
translator to play freely with the traces of meaning and experiment with language to find original solutions, then the theoretical discourse in translation studies may gradually shift its focus to gain, multiplicity, and creativity. To return to Beebee's suggestive "black box" metaphor and his claim that transmesis may grant us further insight into the mysterious nature of translation, it is not unlikely that the box may as well be empty or rather, in Derridean words, full of traces that mark the absence of presence. Or perhaps, translators already know what's in the box, as they are always already in it, in this labyrinth, this funhouse of language which offers ample opportunity for play but from which one can never really escape. 


\section{REFERENCES}

Barthes, Roland. Image, Music, Text. Trans. Stephen Heath. London: Fontana Press, 1987.

—. The Pleasure of the Text. Trans. Richard Miller. New York: Hill and Wang, 1975.

Benjamin, Walter. Illuminations. New York: Harcourt, Brace \& World, 1968.

Beebee, Thomas. "Inside the Black Box of Literary Translation: Transmesis." Expressions

(Mishima, Japan) 3 (2007): 24-44.

—. Personal home page. "Attempt at a Self-Critique.” N. p. Web. 14 Nov. 2010.

$<$ http://www.personal.psu.edu/tob/self.htm $>$.

—

Translational Fiction." Serbian Studies 18.2 (2004): 339-59.

Borges, Jorge Luis. Ficciones. New York: A.A. Knopf, 1993.

Derrida, Jacques. Of Grammatology. Trans. Gayatri Chakravorty Spivak. Baltimore: Johns Hopkins University Press, 1997.

Gadamer, Hans-Georg. Asthetik Und Poetik: I. Tubingen: Mohr, 1993.

Gambier, Yves, and Luc van Doorslaer. The Metalanguage of Translation. Amsterdam: John Benjamins Pub. Co, 2009.

Gasche, Rodolphe. The Tain of the Mirror: Derrida and the Philosophy of Reflection.

Cambridge, Mass: Harvard University Press, 1986.

Hutcheon, Linda. A Theory of Parody: The Teachings of Twentieth-Century Art Forms.

Urbana: University of Illinois Press, 2000.

Ivanov, Mikhail. Survival Russian: An Insider's Guide to the Words, Phrases, Idioms, and

Customs You Need to Survive, and Thrive, in Russia. Montpelier, VT: Russian Life Books, 2007.

Jakobson, Roman. "On Linguistic Aspects of Translation." The Translation Studies Reader.

Ed. Lawrence Venuti, Florence, KY: Routledge, 1999. 113-118. Web. 2 April 2011.

Lefevere, André. Translation, History, Culture: A Sourcebook. London: Routledge, 1992.

Ebrary. Web. 5 May 2011.

Lewis, Philip E. "The Measure of Translation Effects." The Translation Studies Reader.

Ed. Lawrence Venuti, Florence, KY: Routledge, 1999. 264-283. Web. 10 June 2011.

Munday, Jeremy. The Routledge Companion to Translation Studies. London: Routledge, 2009.

Murphy, Russell E. Critical Companion to T.S. Eliot: A Literary Reference to His Life and

Work. New York: Facts On File, 2007.

Nida, Eugene A. Toward a Science of Translating: With Special Reference to Principles and

Procedures Involved in Bible Translating. Leiden: E.J. Brill, 1964.

"Paronomasia." OED Online. March 2011. Oxford University Press. 10 June 2011

Reiss, Katharina. "Type, Kind, and Individuality of Text: Decision Making in Translation."

The Translation Studies Reader. Ed. Lawrence Venuti, Florence, KY: Routledge, 1999. 160-171.

Web. 10 June 2011.

Robinson, Douglas. “Translation and the Repayment of Debt.” N. p., Web. 4 May 2011.

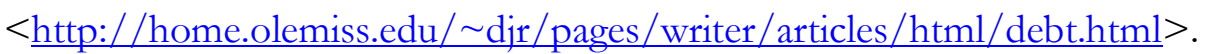

Schäffner, Christina. "Skopos Theory." Routledge Encyclopedia of Translation Studies. Ed.

Mona Baker. London: Routledge, 2001. 235-238. MyiLibrary. Web. 10 June 2011.

Snell-Hornby, Mary. The Turns of Translation Studies: New Paradigms or Shifting

Viewpoints? Amsterdam: John Benjamins Pub. Co, 2006. 
Translation Studies: An Integrated Approach. Amsterdam: John Benjamins Pub. Co, 1988. Spivak, Gayatri Chakravorty. “Translator's Preface.” Of Grammatology. By Jacques Derrida.

Trans. Gayatri Chakravorty Spivak Baltimore: Johns Hopkins University Press, 1997. ixlxxxvii.

The Bible. Biblegateway.com. The Zondervan Corporation, n.d. Web. 9 Feb. 2012. New International Version.

Tompson, William J. Khrushchev - a Political Life. New York: St. Martin's Press, 1995.

Van Vaerenbergh, Leona. "Polysemy and Synonymy: Their Management in Translation

Studies Dictionaries and in Translator Training: a Case Study.” Eds. Yves Gambier and Luc van Doorslaer. The Metalanguage of Translation. Amsterdam: John Benjamins Pub. Co, 2009.

Zhadan, Serhii. Depesh Mod. Kharkiv: Folio, 2009. 